
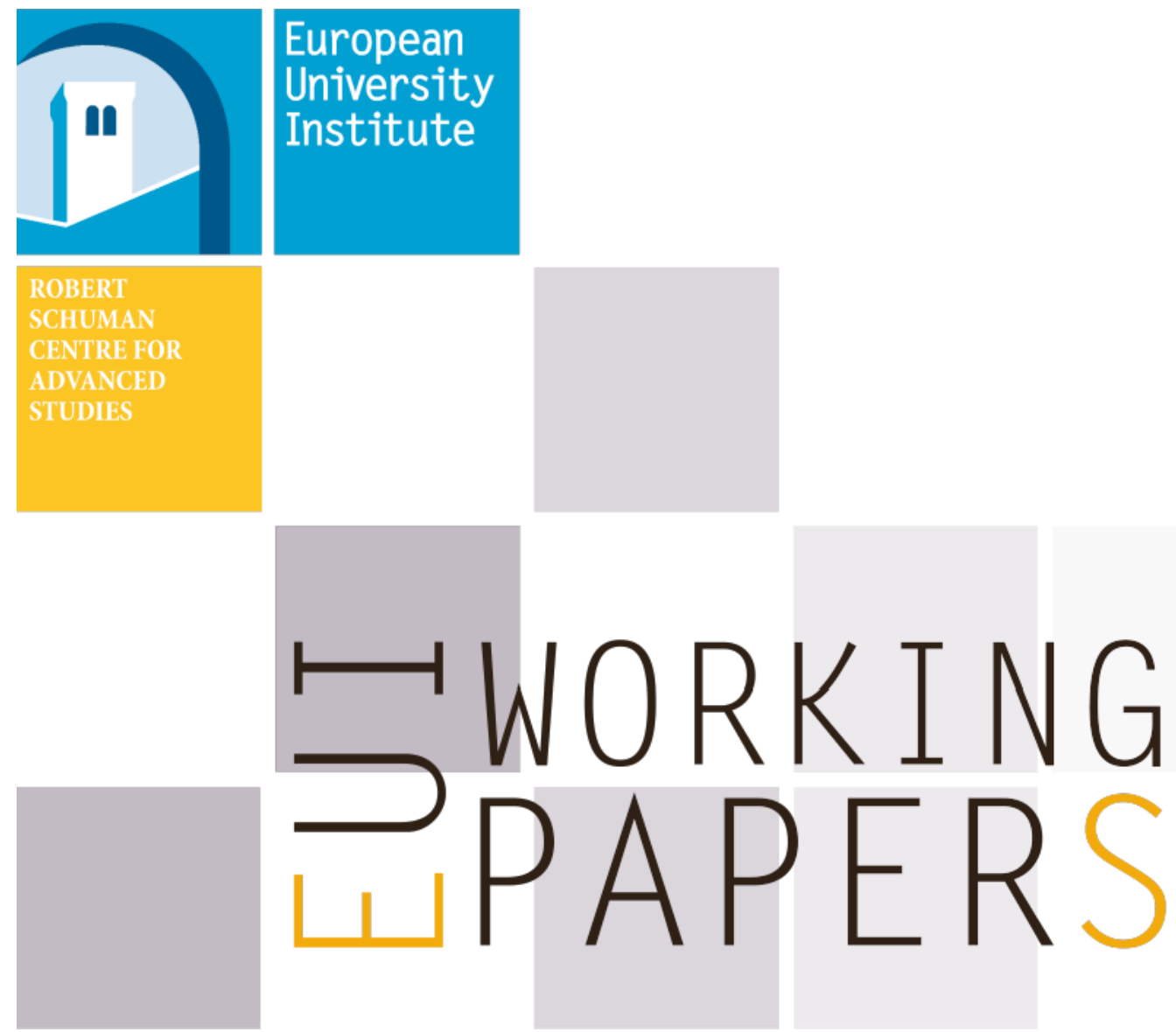

RSCAS 2020/24

Robert Schuman Centre for Advanced Studies

The European Governance and Politics Programme

Differentiated EU Integration: Maps and Modes

Frank Schimmelfennig and Thomas Winzen 

European University Institute

Robert Schuman Centre for Advanced Studies

The European Governance and Politics Programme

\section{Differentiated EU Integration: Maps and Modes}

Frank Schimmelfennig and Thomas Winzen

EUI Working Paper RSCAS 2020/24 
Terms of access and reuse for this work are governed by the Creative Commons Attribution 4.0 (CCBY 4.0) International license. If cited or quoted, reference should be made to the full name of the author(s), editor(s), the title, the working paper series and number, the year and the publisher.

ISSN 1028-3625

(C) Frank Schimmelfennig and Thomas Winzen, 2020

This work is licensed under a Creative Commons Attribution 4.0 (CC-BY 4.0) International license. https://creativecommons.org/licenses/by/4.0/

Published in April 2020 by the European University Institute.

Badia Fiesolana, via dei Roccettini 9

I - 50014 San Domenico di Fiesole (FI)

Italy

Views expressed in this publication reflect the opinion of individual author(s) and not those of the European University Institute.

This publication is available in Open Access in Cadmus, the EUI Research Repository: https://cadmus.eui.eu 


\section{Robert Schuman Centre for Advanced Studies}

The Robert Schuman Centre for Advanced Studies, created in 1992 and currently directed by Professor Brigid Laffan, aims to develop inter-disciplinary and comparative research on the major issues facing the process of European integration, European societies and Europe's place in $21^{\text {st }}$ century global politics.

The Centre is home to a large post-doctoral programme and hosts major research programmes, projects and data sets, in addition to a range of working groups and ad hoc initiatives. The research agenda is organised around a set of core themes and is continuously evolving, reflecting the changing agenda of European integration, the expanding membership of the European Union, developments in Europe's neighbourhood and the wider world.

For more information: http://eui.eu/rscas

The EUI and the RSCAS are not responsible for the opinion expressed by the author(s).

\section{The European Governance and Politics Programme}

The European Governance and Politics Programme (EGPP) is an international hub of high quality research and reflection on Europe and the European Union. Launched in 2018, it is part of the research programmes of the Robert Schuman Centre for Advanced Studies at the European University Institute.

The EGPP maintains its core activities through externally funded research projects, including financial support from the European Commission through the European Union budget, and is animated by the Programme Associates, leading scholars from different disciplines brought together by their interest in European integration and its future development.

For more information: http://europeangovernanceandpolitics.eui.eu/ 



\begin{abstract}
This paper reports a descriptive analysis of the historical development and the modes of differentiated integration in the treaties and legislation of the European Union. Whereas the number of differentiations has increased in the course of European integration, it has remained stationary relative to the growth of the EU's membership, policy portfolio and legal production. Differentiated integration is predominantly multi-speed integration, typically originating in enlargement, focusing on internal market policies and affecting the comparatively poor Southern and Eastern new member states. In addition, durable differentiations originating in the deepening of the integration of core state powers have created a multitier structure, but the core is inclusive and open. The crisis period of European integration has reinforced the differentiation of the EU for the time being, but both Brexit and the stagnation of widening and deepening are likely to slow down differentiation.
\end{abstract}

\title{
Keywords
}

Differentiated integration, European law, European Union, integration history 



\section{Introduction}

This report from the InDivEU project provides a descriptive analysis of differentiated integration (DI) in the EU. It updates the descriptive analysis in Schimmelfennig and Winzen (2020, Chapter 4) with the most recent data in the EUDIFF1 and EUDIFF2 datasets, bringing the analysis of treaty-based differentiation up to 2019 and the analysis of legislative differentiation up to $2018 .{ }^{1}$ It describes and discusses the basic trends and patterns of DI since the beginnings of European integration and highlights important recent developments.

After defining our key concepts (Section 1) - differentiation and its modes - we describe the development of DI throughout the EU's history since the 1950s, in treaty law as well as in EU legislation (Section 2). Sections 3-5 map DI by duration, country (groups) and policy (areas) and assess the extent to which DI corresponds to the modes of multi-speed, multi-tier and multi-menu differentiation. In Section 6, we provide an outlook on the development of DI in the near feature, taking into account its recent trajectory, important current events such as Brexit and likely developments in treaty and legislative change. Section 7 concludes.

These are our most important findings:

1. The number of differentiations has increased in the course of European integration, but remained stationary relative to the growth of the EU's membership, policy portfolio and legal production.

2. Differentiated integration in the EU is predominantly multi-speed integration. Most differentiations negotiated in the history of the EU by far have expired after a few years. Multispeed integration originates in enlargement, focuses on internal market policies and affects comparatively poor Southern and Eastern new member states predominantly.

3. Durable differentiations have created a multi-tier structure, but the core is inclusive and open. Multi-tier integration originates in treaty revisions, concerns the integration of core state powers and consists of opt-outs for comparatively Eurosceptic Northern and Eastern member states.

4. Differentiated integration in the EU is not multi-menu integration. The differentiated EU has preserved common institutions and a large core membership that participates in all policies.

5. The crisis period of European integration has reinforced the differentiation of the EU for the time being, but both Brexit and the stagnation of widening and deepening are likely to slow down differentiation.

Overall, differentiation has been a companion of progressive integration. It has facilitated intergovernmental agreement on the expansion of the EU's membership, policy portfolio and competencies by introducing exceptions that accommodate the heterogeneity of member states and overcome their opposition. Progress in integration is accompanied by more differentiation; less differentiation comes with integration gridlock. Perhaps counterintuitively, uniform integration is a sign of stagnation.

1 This paper was funded by the European Union's Horizon 2020 research and innovation programme under grant agreement No 822304. The content of this paper represents only the views of the authors and is their sole responsibility. The European Commission does not accept any responsibility for use that may be made of the information it contains.

For their contribution to preparing and coding the update of the EUDIFF2 dataset, we thank Christian Frommelt at the Liechtenstein Institut and Jana Lipps, Ronja Sczepanski, Massimo Troncone and Yaron Weissberg at ETH Zurich. We further wish to thank Marta Migliorati, Sebastiaan Princen and Robert Zbíral for feedback during the coding process. 


\section{Differentiations and modes of differentiated integration: key concepts}

\section{Differentiations}

Our descriptive analysis is based on 'differentiations'. We count differentiations over time, across member states and integrated EU policies. What then is a 'differentiation'? We begin with a legal definition of European integration: the body of binding formal rules of the EU to which states agree to adhere. These rules can be uniform or differentiated. Uniform rules are equally valid in all member states, whereas differentiated rules are not uniformly legally valid across the EU's member states. ${ }^{2}$ For a legal rule to count as differentiated, at least one member state must be legally exempt or excluded from the rule for some time. Thus, our basic operational definition of a differentiation is a member state-legal rule-year triad. Each instance of an EU legal rule that is not legally valid in a given member state in a given year counts as one differentiation. Starting from this basic approach, we use different methods in EU treaties and legislation to aggregate legal rules into differentiations.

In the case of treaty-based differentiations, the EUDIFF1 dataset codes the main treaties of the EU and its predecessor organizations, starting with the Treaty establishing the European Coal and Steel Community in 1952 and moving on to the Treaties of Rome, the Treaty on European Union (TEU) and their various revisions up to the Treaty of Lisbon. EUDIFF1 further includes treaties that were incorporated eventually into the main treaties (such as the Schengen agreement) or are intended to be incorporated at a later stage (such as the Fiscal Compact or the ESM Treaty). In addition, it considers accession treaties insofar as they introduce differentiation into the main treaties. The records in the EUDIFF1 dataset code differentiated integration by treaty article and year.

While it would seem straightforward to base the count of differentiations on the number of treaty articles that exempt any of the member states each year, we decided in favour of a more aggregated measure. The obvious problem is that the number of articles that regulate treaty policy regimes such as the free movement of workers, the Eurozone or the Schengen area can differ dramatically. The freedom of movement of workers is regulated in a single article, the Eurozone in some 30 articles, and Schengen in 175. This difference clearly does not reflect the importance of these policy regimes. Moreover, when countries negotiate opt-outs from the EU treaties, they do not do so article-by-article but rather policy regime by policy regime. Corresponding to this, our approach is to categorize the treaty into its many distinct policy regimes (42 in 2018). Here we follow the structure of the treaties themselves, which also constitutes the basis for intergovernmental negotiations over treaty reform and enlargements. ${ }^{3}$ Each time a country is not bound by the EU treaty rules on a policy, we count a differentiation. In other words, the British opt-out from the Schengen area counts as one rather than as 175 differentiations. ${ }^{4} \mathrm{We}$ thus arrive at 230 distinct treaty-based differentiations in the history of the EU.

In the case of legislative differentiations, we code regulations and directives (of the Council or the Council and the Parliament) ${ }^{5}$ and use the legal act (rather than its individual articles) as the unit of analysis. Each exemption or exclusion of a member state from the regulation or directive (no matter how many articles are affected) counts as one differentiation.

2 We do not take into consideration 'external differentiation' in this paper, i.e. the selective adoption of EU rules by nonmember states.

3 See Table A1 in the Appendix for an overview and typology of these policy areas.

4 We do allow for a limited number of cases of multiple differentiations from a policy area. That is, differentiations that start at distinct points in time are counted as distinct differentiations even if they are in the same policy area and for the same country.

5 In addition, decisions adopted by the Council or the Council and the European Parliament jointly in the Third Pillar (Police and Judicial Co-operation in Criminal Matters (PJCCM)) between 1993 and 2009 must be considered as a third source of legal rules and, hence, of differentiation as they have the same function as regulations in the First Pillar (European Community). 
Our datasets and analyses further distinguish differentiations by their origins (enlargement or widening vs. treaty revisions or deepening), their durability, the (groups of) countries they concern and the policies they affect. These features are important to examine the modes of differentiation to which we now turn.

\section{Modes}

Following Stubb (1996), but relabelling his categories, we distinguish three modes of differentiated integration: multi-speed, multi-tier and multi-menu differentiation (Schimmelfennig and Winzen 2020: Chapter 2).

Differentiation by time generates a pattern in which DI is a transitional phenomenon. Integration converges towards uniformity. When member states decide to accept new members or deepen integration, they agree on initial exemptions for some states and rules, which will expire over time. According to this pattern, we should observe that differentiations for each legal rule and each member state decrease over time and disappear eventually. Stubb (1996: 287) proposes the term 'multi-speed' integration for this mode.

Differentiation by space generates a pattern in which DI is permanently structured along groups of states, hierarchically ordered from core to periphery or from inner to outer circles of integration. Within each group of states, the level of integration is similar. The core is uniformly integrated; it has no or only minor differentiations. As we move out from the core to the periphery, the extent of differentiation increases. The term that Stubb uses for this mode, 'variable geometry', is not intuitive. Better terms are 'concentric circles' or, in line with multi-speed integration, 'multi-tier' integration.

Finally, differentiation by matter produces a pattern in which policies structure DI permanently. In this pattern, integration within each policy or policy area is roughly uniform. The participating states vary, however, from policy to policy. States pick and choose from the menu of policies, and each state puts together its own set of 'courses'. There is no general convergence towards uniformity, nor is there a stable core of uniformly integrated member states. This is 'Europe à la carte' in Stubb's typology (1996: 288). In contrast with multi-speed and multi-tier integration, we speak of 'multi-menu' integration.

\section{The historical development of differentiated integration}

Figure 1 shows the results of counting differentiations in EU treaties (panel a) and legislation (panel b) over time. The overall picture is indeed one of increasing differentiation in primary and secondary law. Generally, both revisions of the main treaties and accession treaties have driven up the number of treatybased differentiations. After a long initial period of low and stable differentiation, the enlargements of 1973, 1981 and 1986 are responsible for the first spikes in the line. Yet, only the 2004 accession of ten new member states constitutes a watershed in terms of the number of treaty differentiations. When Bulgaria and Romania joined in 2007, the number of treaty-based differentiations reached an all-time high.

In addition, precipitous changes follow from the adoption of the intergovernmental Schengen Agreement and Prüm Convention as well as the Treaty establishing the European Stability Mechanism (ESM), the TSCG and the Intergovernmental Agreement on the Single Resolution Fund (SRF) of the Banking Union. By contrast, revisions of the main treaties from the Single European Act (SEA) in 1987 to the Treaty of Nice in 2003 increased DI only mildly. The marked rise of differentiations in the Treaty of Lisbon in 2010 is an exception. The introduction of Permanent Structured Cooperation (PESCO) in the area of security and defence has been the most recent source of growing differentiation. 
Figure 1 The development of differentiation in EU treaties and legislation

a) Differentiation in EU treaties, 1958-2018

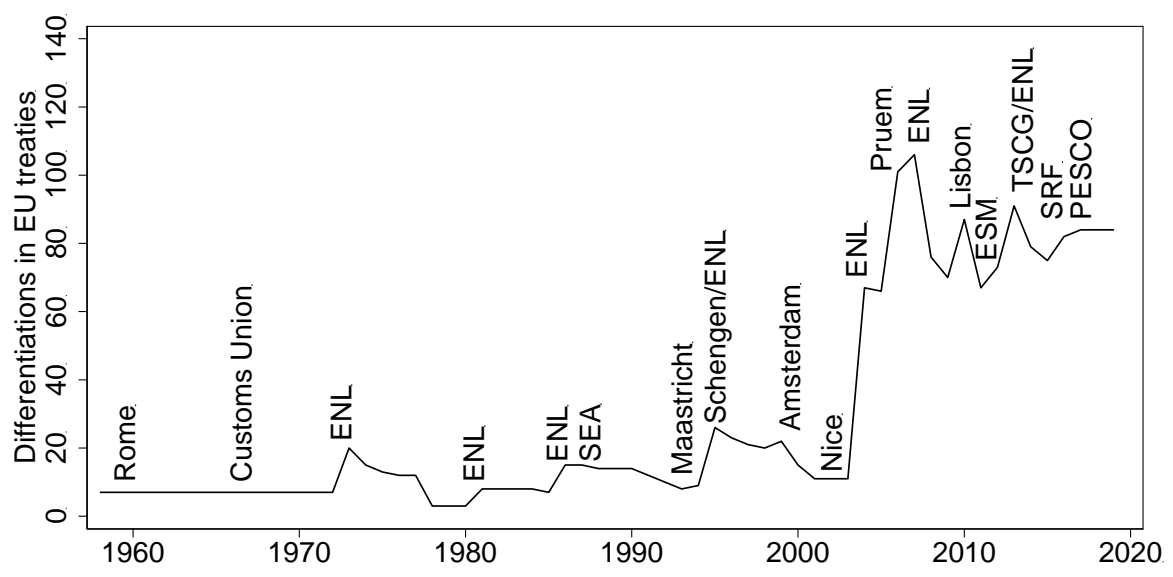

b) Differentiation in EU legislation, 1958-2012

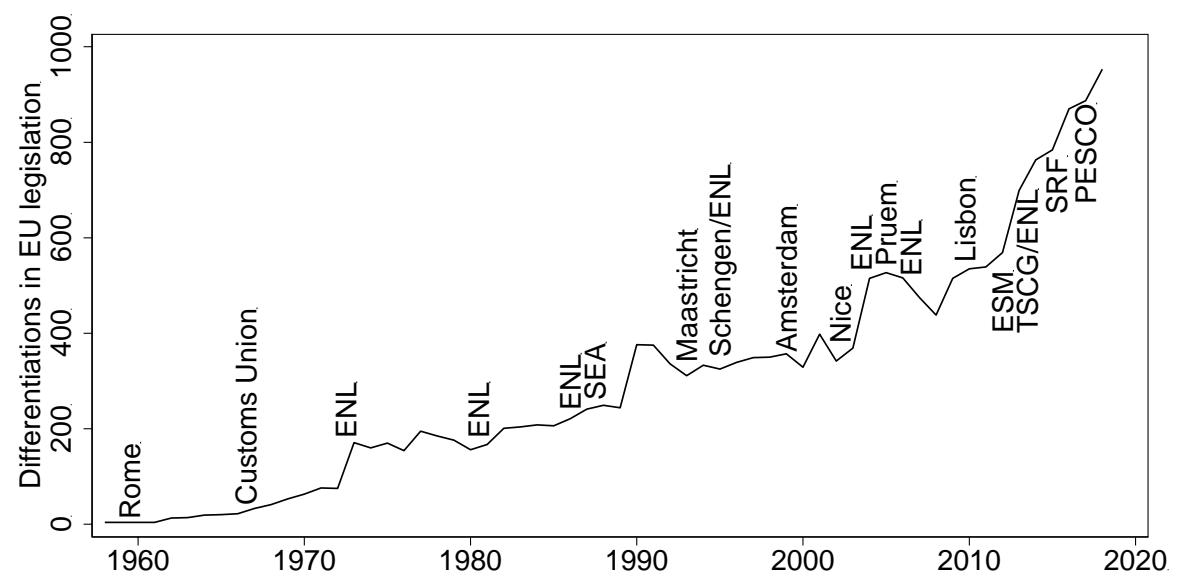

Source: Panel a: Updated from Schimmelfennig and Winzen (2014, 2020). Panel b: Adapted from Duttle et al. (2017) and updated from Schimmelfennig and Winzen (2020). ENL: Enlargement (1973: Denmark, Ireland, United Kingdom. 1981: Greece. 1986: Portugal and Spain. 1995: Austria, Finland, Sweden. 2004: Eight central and East European countries, Cyprus, Malta. 2007: Bulgaria and Romania. 2013: Croatia).

Whereas treaty-based DI has experienced a major step change in differentiation levels in the mid-2000s, the picture in secondary law is one of long-term gradual accumulation for most of the EU's history. In addition, every enlargement round has resulted in new differentiations. In addition to Eastern enlargement, German unification in 1990 has contributed strongly to legislative differentiation - an effect we do not see in the treaties at all. Finally, after a temporary decline after the 2007 Eastern enlargement round, we observe a steep increase in legislative differentiation in the period in which the EU faced the global financial, Eurozone, and refugee crises. In both treaties and legislation, we see that the number of differentiations does not rise linearly. Enlargement peaks in particular are followed by gradual decline as differentiations expire over a period of a few years.

The development of differentiation in absolute numbers overstates the trend towards more DI, however, because it does not take into account the expansion of European integration that has taken place in the same period. Since 1958, the number of EU policies and laws as well as member states has multiplied, and each additional treaty article, piece of legislation and new member state creates 
additional differentiation opportunities. Figure 2 therefore shows DI relative to the number of member states and issue-areas in the EU treaties (panel a) and legislation in force (panel b).

The tendency of differentiation to rise and decline after enlargements is still visible in Figure 2. However, we cannot speak of an unambiguous long-term trend towards ever more differentiation. In 2019, member states used some seven percent of differentiation opportunities in EU treaty law, much the same as at the 1958 foundation of the European Economic Community (EEC). In relative terms, Eastern enlargement has not led to a higher level of DI than the Northern enlargement of 1973. It seems, however, that DI has established a higher base level after 2004 and will not return to the two-percent level, as after earlier enlargement rounds.

Figure 2 Differentiations in the EU relative to opportunities

a) Differentiation in EU treaties

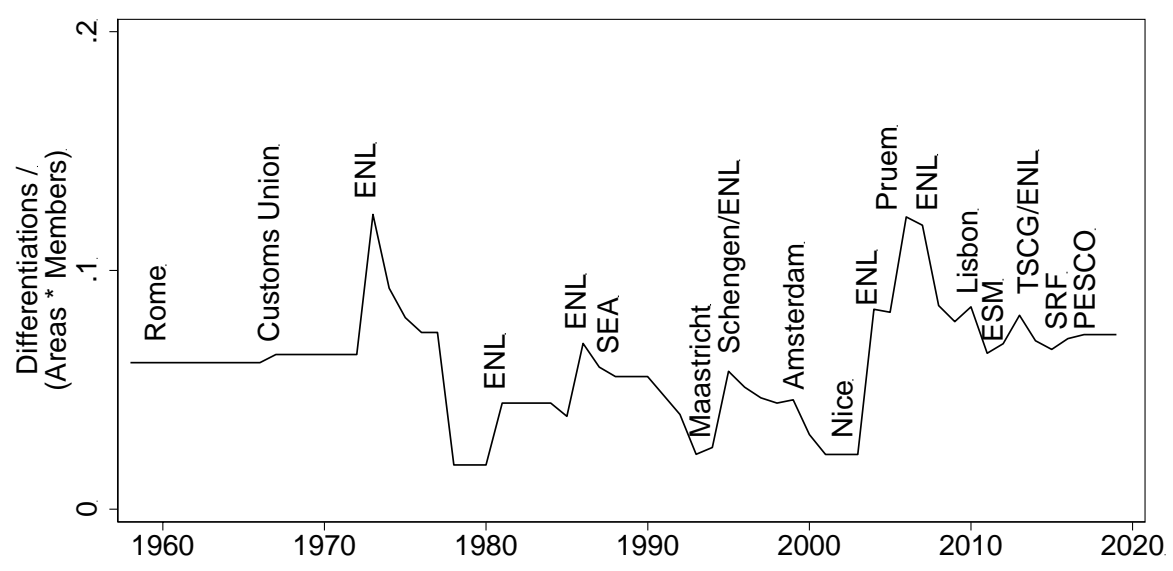

b) Differentiation in EU legislation

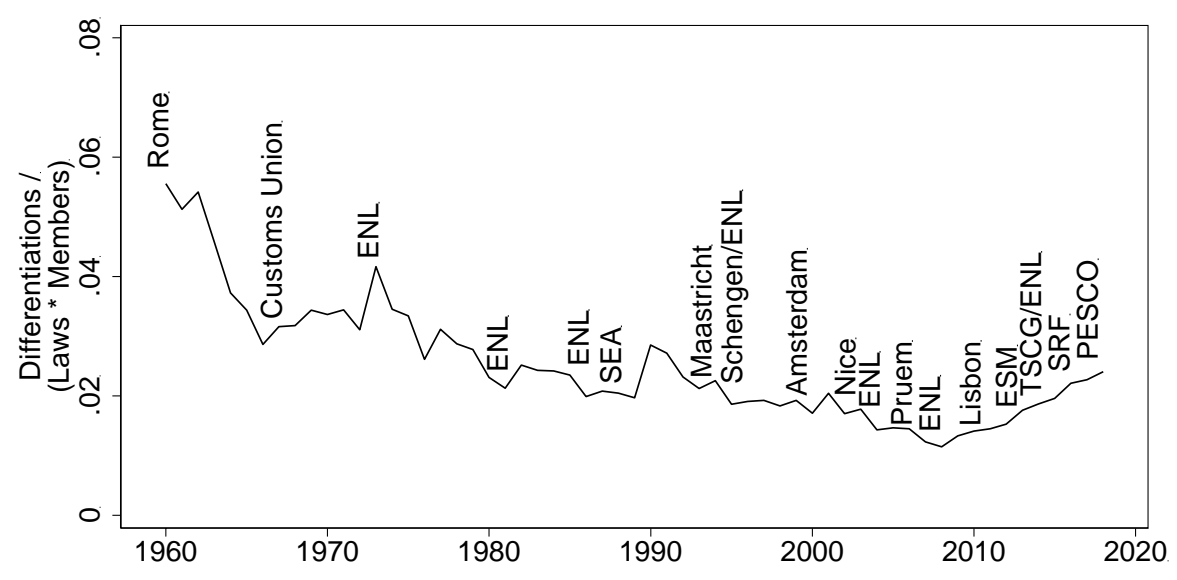

Source: Panel a: Updated from Schimmelfennig and Winzen $(2014,2020)$. Panel b omits 1958 and 1959. The share of differentiation was above 20 percent in 1958 and still 10 percent in 1959 but EU secondary law consisted of only 20 (1958) and 40 (1959) pieces of legislation.

In secondary legislation, the seeming upward trend we saw above in fact turns into a long-term trajectory towards uniformity that lasted until 2008. The early 1960s in which the EU's acquis contained very few laws makes this trend appear somewhat more extreme than it is. Yet, at the very latest the late 1960s, after the completion of the Customs Union, constitute a valid starting point. Even since then a clear downward trend has materialized. By 2008, member states were using just above one percent of their 
legislative differentiation opportunities. Figure 2, in comparison to Figure 1, makes clear that law production has outpaced the accumulation of legislative differentiations for most of the Union's history.

However, this situation has changed with the rise in differentiation since 2008. Since then, the share of legislative differentiation has more than doubled from 1.1 to 2.4 percent. While this trend has been accentuated by a decline in EU legislative activity (and corresponding differentiation opportunities) between 2010-2012, it is predominantly driven by a large increase in ongoing differentiations from 438 in 2008 to 953 in 2018. This post-2008 rally has largely jeopardized the long-term trend towards uniformity. The 2018 level had last been exceeded in 1990-1991 after German unification and, before then, in 1982-1984 after Greece joined the EU. Yet even the rise in relative legislative differentiation since 2008 remains within the long-term range of secondary-law DI established since the late 1960s. We do not see the same post-2004 step change as in treaty-law DI. It is possible, however, that this step change has 'trickled down' to secondary law to some extent.

Taken together, the two figures suggest that differentiation increases with integration progress in general and instances of EU deepening and widening in particular. Quantitatively, the effect of EU enlargements has been particularly pronounced. Yet, the figures warrant caution as to the unconditional interpretation that differentiation is becoming ever more widespread in the EU. More cases of DI in treaty and secondary law, especially in the 2000s, after enlargements, and after intergovernmental treaties constitute one side of the story. The other is the stability of treaty-based DI relative to differentiation opportunities, the growing relative uniformity in EU legislation until 2008 and the transitory nature of the differential treatment of new member states. The stability of weighted treatybased DI indicates that differentiation has largely served to facilitate - and compensate for - the growth of European integration. In our interpretation, it has accommodated the increasing heterogeneity of EU member states and the contestation about the European integration of core state powers. Moreover, the long-term decrease of weighted legislative differentiation testifies to the harmonizing capacity of EU law-making - at least at the level of the formal validity of legislation. The rapid increase in weighted and absolute legislative differentiation after 2008 puts this observation into perspective, however. Understanding whether this development is a temporary result of the multiple crises of this period or a more lasting feature, for instance as a consequence of the higher level of treaty-based DI, requires further analyses at the country and policy level. Finally, the differential treatment of new member states appears to be transitory for the most part.

\section{Multi-speed integration: transitory differentiation, common destination}

Multi-speed integration is characterized by temporal differentiation. If European integration conformed to the multi-speed mode of differentiation, we should observe that differentiations are temporary and have a moderate duration, and that differentiations in new member states decrease over a reasonable period of time. Multi-speed integration further assumes that European integration will become uniform (again) in the end. Because the EU continues to admit new member states, expand its tasks, and centralize decision-making, we cannot observe, however, whether this assumption is correct. The analysis will therefore focus on the duration and termination of individual differentiations.

Of the total of 230 treaty-based differentiations, 146 (or 63\%) had expired before 2019. Of the 84 differentiations still active in 2019 , many are likely to expire at some point in the future. In sum, the great majority of differentiations follow the pattern of multi-speed integration: temporary exemptions from eventually uniform EU rules.

The mean duration of treaty-based differentiations is seven years and nine months; the median is seven years. The 146 terminated differentiations have even expired after five years and seven months, on average. Only 37 differentiations (16 percent of the total) have lasted for 14 years or longer (i.e., more than one standard deviation above the mean). Of the 84 differentiations still active in 2019, 30 meet this threshold for durable differentiations. These differentiations are the most likely to defy the mode of multi-speed integration: the Eurozone non-membership of the UK, Denmark, Sweden, the 
Czech Republic, Hungary, and Poland; the Schengen non-membership of the UK, Ireland, and Cyprus; Denmark's opt-out from the common defence policy; exemptions from the free movement of capital (mainly relating to foreign ownership of land property) for Denmark, Estonia, Malta, and Hungary; and exemptions from Justice and Home Affairs for Denmark, the UK, and Ireland. The list suggests that durable differentiations cluster in a small number of member states (above all Denmark and the UK) and specific policy areas (especially monetary and interior policies).

Multi-speed integration implies that member states have most differentiations when they join, and that the number of differentiations decreases over the duration of membership. In this case, DI serves to facilitate intergovernmental agreement both by postponing the effects of heterogeneity and based on the expectation that heterogeneity will decrease over time. In line with this implication of multi-speed integration, Figure 3 shows that the average number of treaty-based differentiations of new member states drops from 4.4 in the year of accession to 1.8 twelve years later. As the figure also shows, new member states often acquire additional differentiations in the first years of membership; then the number of differentiations drops sharply between years 3 and 8, i.e., around the average duration of terminated differentiations. Yet the mean for all member states masks significant variation across accession cohorts. Whereas the 1995 accession countries (Austria, Finland and Sweden) had ended almost all differentiations in the first seven years of membership, the most recent members (Bulgaria, Croatia and Romania) not only started, but also remained at a much higher level of initial differentiation during the same period. This may indicate that the pattern of multi-speed differentiation does not equally hold for the newest EU members.

\section{Figure 3 Treaty-based differentiation in new member states}

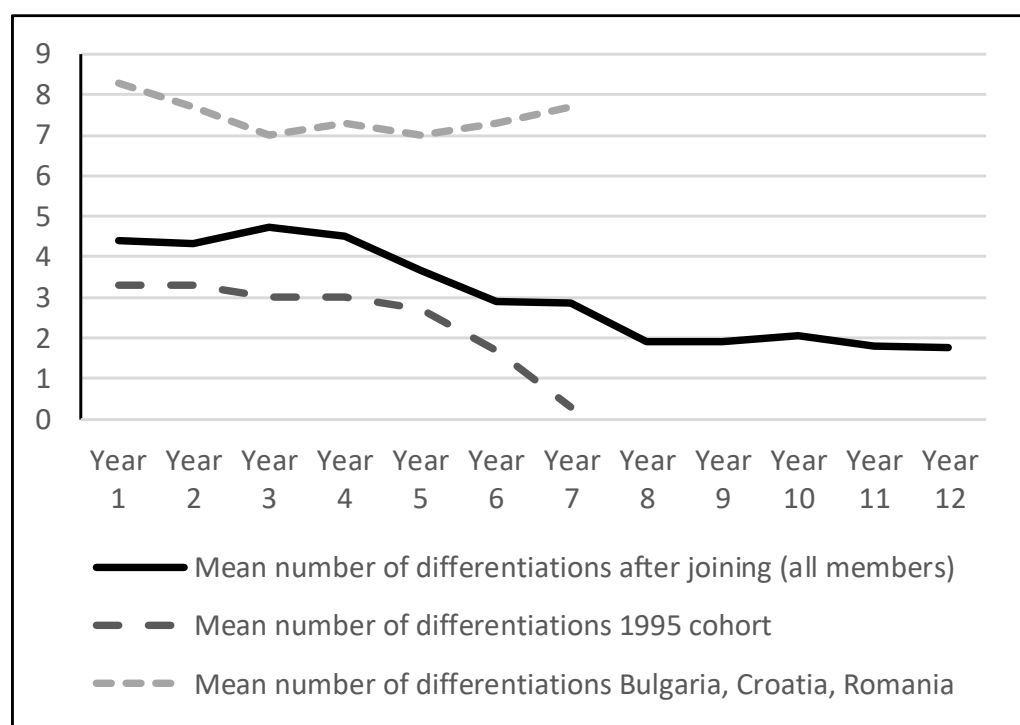

Note: Mean number of differentiations of new member states in the first twelve years after accession (without Croatia). Adapted from Schimmelfennig and Winzen (2020).

Shifting our attention from EU treaties to legislation, we again see evidence of a consolidation trajectory and declining differentiation after enlargements until the 2008 change in the overall trend. Figure 4 shows separate graphs for each accession cohort, which reveal a broadly similar picture. The Northern (panel b) and Southern (panel c) accession cohorts joined the EU with many legislative differentiations or accumulate these in the first years of membership. The EFTA cohort followed this pattern, albeit far less clearly. For the countries that joined the EU after 2000, opt outs from legislation were initially very rare - in line with or below the levels of differentiation of older member states at the time. With one exception, all cohorts quickly converged towards the long-term consolidation trend led by the founding member states. This is also true for a special kind of enlargement: the 'accession' of the former German Democratic Republic to the Federal Republic Germany and, thus, to the EU. While German unification 
caused an extraordinary amount of special treatment in EU legislation, these differentiations quickly dissipated during the 1990s.

Figure 4 Legislative differentiation in accession cohorts

a) Founding members

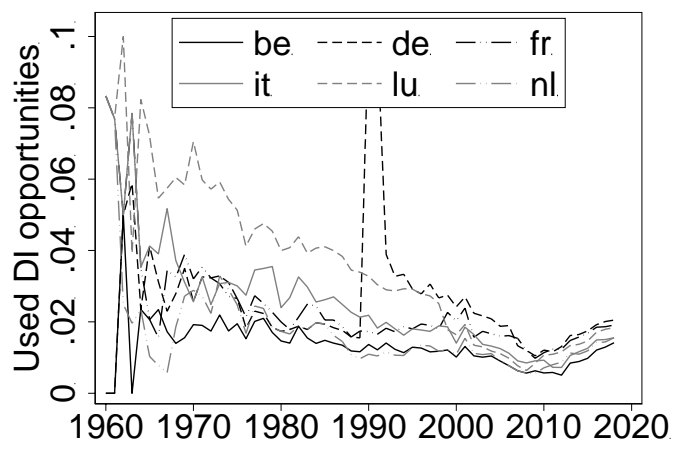

c) Southern enlargement

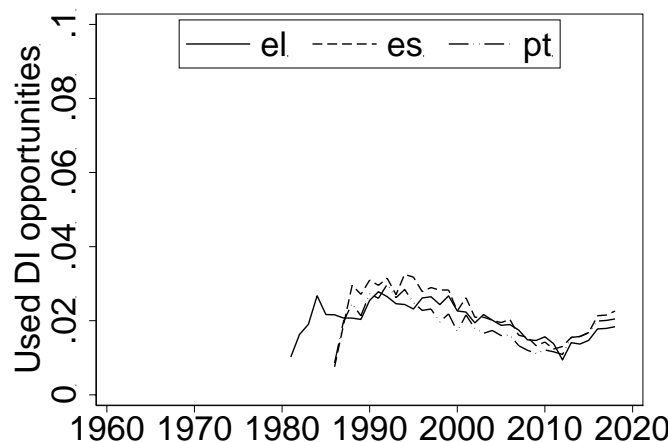

e) Eastern enlargement I

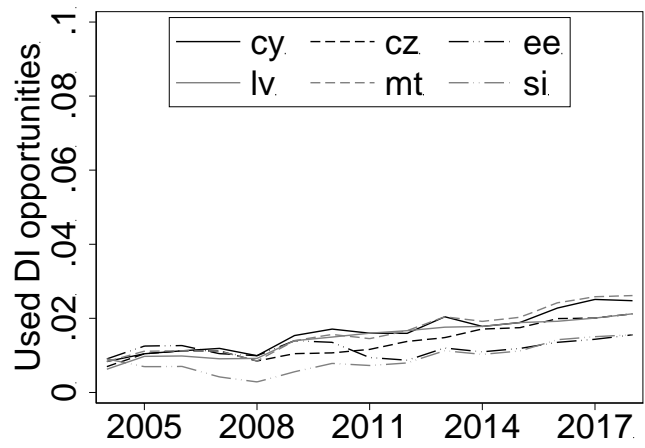

b) Northern enlargement

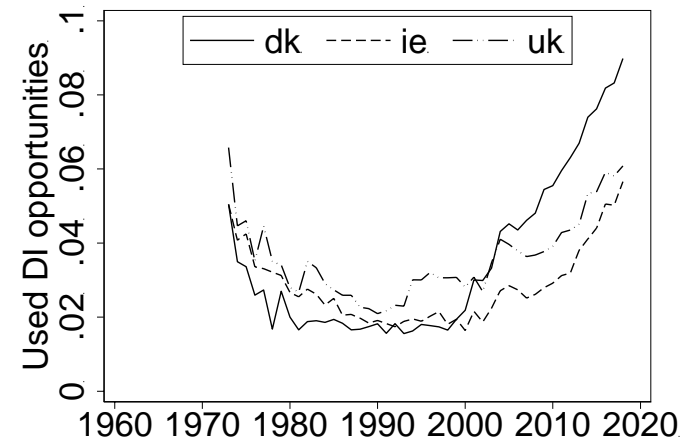

d) EFTA enlargement

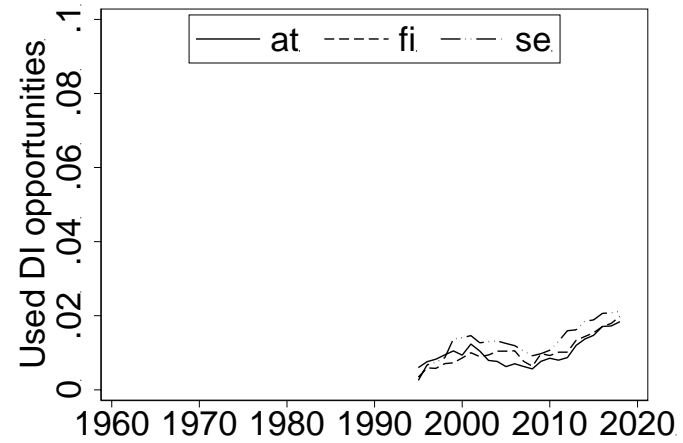

f) Eastern enlargement II

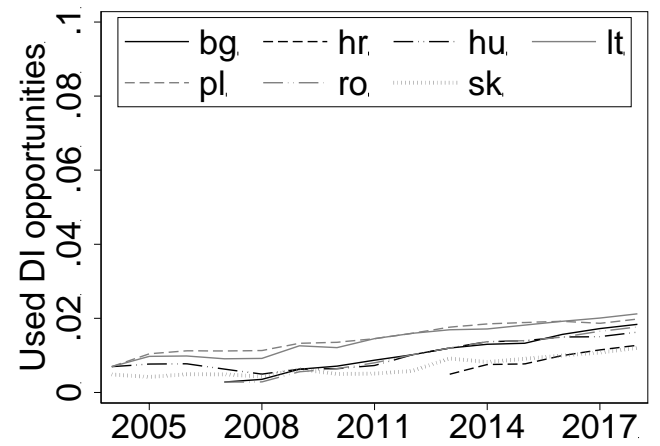

Note: The share of differentiation opportunities used by EU member states, separated by accession cohorts. Updated from Schimmelfennig and Winzen (2020).

The Northern cohort constitutes the one clear-cut exception from the otherwise remarkably uniform development of legislative differentiation. After their accession in 1973, Britain, Denmark and Ireland initially converged towards levels of differentiation similar to the founding and Southern cohorts. 
However, in the 1990s, unlike these member states, the Northern countries began to accumulate new differentiations and have since followed this path. This is a deviation from the mode of multi-speed integration.

Finally, since 2008 all member state cohorts have left the paths towards uniform integration and instead contributed about equally to growing differentiation. The trends continue to be notably similar, and the Northern cohort continues to follow a more extreme trajectory than the other countries, but the direction has changed from progress towards integration to growing differentiation.

In addition, we can ask whether multi-speed integration in the EU has changed over time. For this purpose, we calculate the average duration of differentiations (in treaty law) starting in a given year and the share of terminated differentiations among all differentiations starting in that year. If differentiations turned out to become more short-term over time, and more likely to be terminated, this would reveal a strengthening of the EU's consolidation capacity. Otherwise, it would indicate that 'multi-speed Europe' is actually losing speed. Table 1 shows the numbers for each year between 1958 and 2013, in which differentiations started. ${ }^{6}$ It is difficult to detect any temporal pattern, however. Long-lasting and brief differentiations can be found at all times. The share of terminated differentiations varies strongly, but again without any temporal direction. DI has not become visibly more or less multi-speed over time.

Table 1 Multi-speed integration over time

\begin{tabular}{lll}
\hline $\begin{array}{l}\text { Starting } \\
\text { year }\end{array}$ & $\begin{array}{l}\text { Mean duration of } \\
\text { differentiations (years) }\end{array}$ & $\begin{array}{l}\text { Share of terminated } \\
\text { differentiations }\end{array}$ \\
\hline 1958 & 22.3 & 1 \\
1973 & 4.9 & 1 \\
1981 & 5.4 & 1 \\
1986 & 7.3 & 1 \\
1993 & 22 & 0.25 \\
1994 & 26 & 0 \\
1995 & 7.2 & 0.9 \\
1999 & 17.2 & 0.2 \\
2004 & 7.3 & 0.9 \\
2006 & 6.2 & 0.6 \\
2007 & 6.9 & 0.7 \\
2010 & 8.9 & 0.2 \\
2012 & 6.9 & 0.2 \\
2013 & 5.8 & 0.2 \\
\hline
\end{tabular}

Note: New treaty-based differentiations starting between 1958 and 2013. Updated from Schimmelfennig and Winzen (2020).

Table 1 shows, however, that durable treaty-based differentiation only started in the 1990s - together with the establishment of the European Union. There are no legacy differentiations left from the first four decades of the European Communities. By contrast, 80 percent of the differentiations that have started since the latest major treaty reform (the Treaty of Lisbon in 2010)) have not ended yet. It is too early to tell, however, whether this observation indicates a change in the multi-speed pattern of DI. Rather than temporal patterns, Table 1 suggests that duration and termination vary with the origins of differentiations. Differentiations starting in years of enlargement (1973, 1981, 1986, 1995, 2004 and 2007) have been much shorter and more likely to be terminated than differentiations starting in years of treaty reform. Differentiations starting in enlargement years have lasted between 4.9 and 7.3 years

6 We dropped new differentiations after 2013 because the time elapsed until 2019 is below the mean duration of terminated differentiations. 
on average, in contrast to 6.2 to 26 years for differentiations starting in years of treaty reform. ${ }^{7}$ More clearly still, the share of terminated differentiations ranges between 70 and 100 percent for accession years, and between 0 and 60 percent for new differentiations in years of treaty reform.

Overall, the 121 differentiations from accession treaties have lasted for 6 years and 7 months on average. ${ }^{8}$ Only seven $(6 \%)$ have been in force for 14 years or longer, and $101(83 \%)$ had ended before 2019. The 101 differentiations agreed on in the context of treaty reform have only lasted one-and-a-half years longer on average ( 8 years and 1 month). Yet, 23 of them (23\%) have already been in force for at least 14 years, and only 38 (37\%) were terminated by 2019 . That is, the rate of ongoing differentiations originating in treaty reform is more than double, and the rate of long-term differentiations almost four times, that of differentiations originating in enlargement. All differentiations that have been in place for a very long time (more than 16 years) started in the context of treaty revisions.

In sum, internal differentiation in the EU is predominantly multi-speed DI. A large majority of differentiations agreed on by the member states in the treaties and laws of the EU have already expired; and they have done so after a reasonable period of time. Our data reinforce the earlier conclusion that DI mostly serves as a temporary facilitator of EU integration and is not the harbinger of ever looser union. However, it remains too early to say conclusively whether the recent rise of differentiation at the level of both treaties and legislation will disappear over time as the EU emerges from a turbulent period, stabilize at the current levels, or continue. At the same time, we observe significant differences in the duration and termination of DI between accession and treaty reform. Multi-speed DI is typical of EU enlargement and the trajectory of EU member states in the post-accession period. Afterwards, however, treaty reforms introduce more long-lasting differentiations among the member states. Do these longterm differentiations constitute the distinct strata of member states that the idea of multi-tier integration expects?

\section{Multi-tier integration: inclusive core, reclusive periphery}

In order to capture the potential multi-tier structure of EU integration, we focus on the 84 treaty-based differentiations in force in 2019, the most recent year of the EUDIFF1 dataset. Figure 5 shows both the number of differentiations that each member state has had since the beginning of its membership in the EU and the number of ongoing differentiations in 2019.

The figure suggests that we can currently broadly distinguish three distinct tiers or circles of membership: a core group of member states with at most a single ongoing differentiation, a second tier with 5-7 differentiations (the 'semi-periphery') and a peripheral group with 11-12 differentiations. Cyprus, Ireland and Malta (2-4 differentiations) are in between the core and semi-periphery; Croatia (9 differentiations) is in between the semi-periphery and the periphery. As we move from the core to the periphery, the size of the groups becomes smaller: 16 in the first tier, six in the second tier, and only two (Denmark and the UK) in the third. This top-heavy pattern indicates that EU multi-tier integration is not dominated by a small vanguard of highly integrated core countries but produced by a small group of laggards and refusers. This is not the pyramid structure typical of hierarchical core-periphery relations, but rather an inverted pyramid.

\footnotetext{
7 We exclude 2013, which is recent and includes both enlargement (the accession of Croatia) and treaty reform (the Fiscal Compact). We also exclude differentiations from the founding treaties in 1958. 
Figure 5 Multi-tier integration in the EU

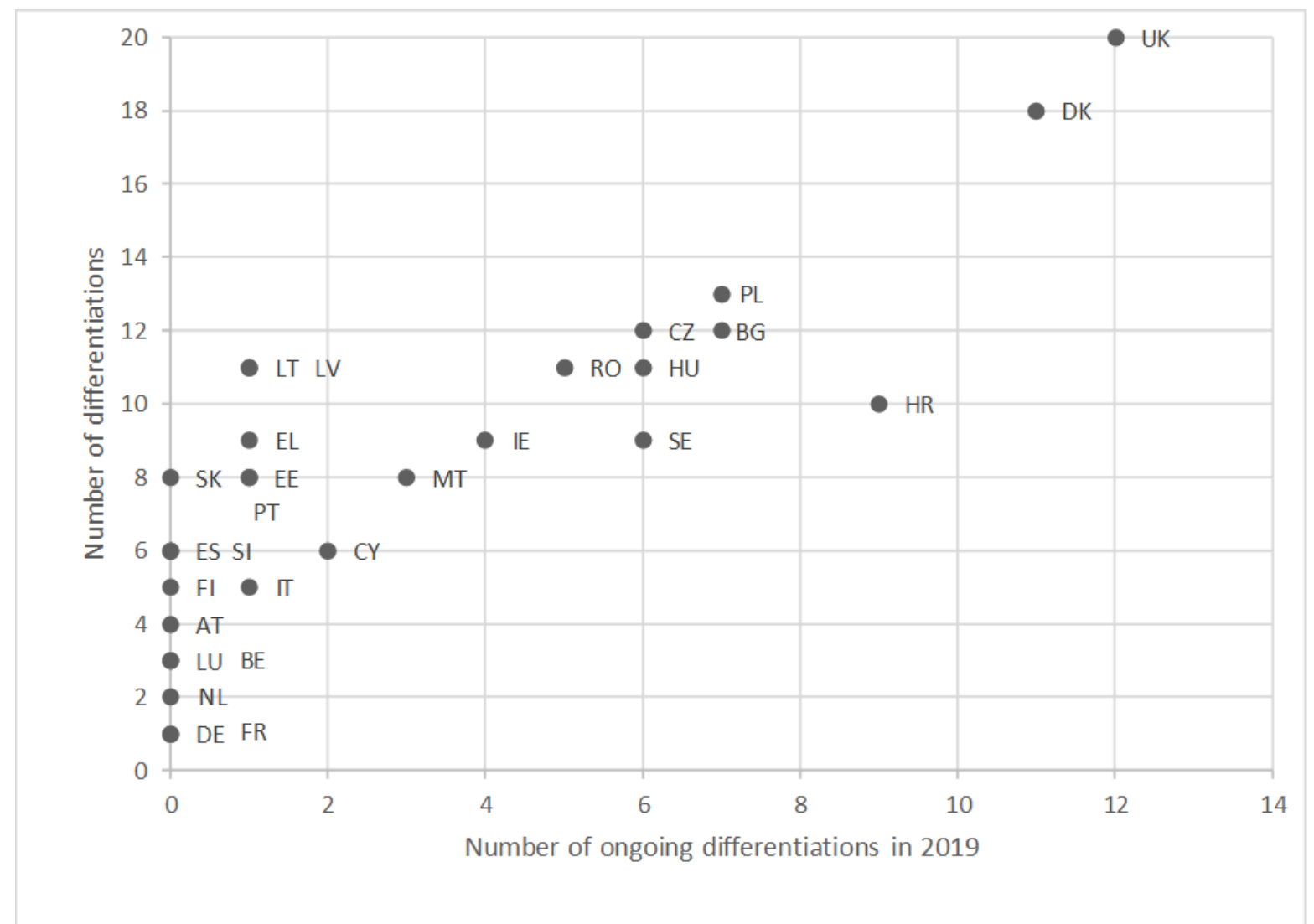

Note: 'Number of differentiations', 1958-2019. 'Ongoing differentiations' at the end of 2019. Updated from Schimmelfennig and Winzen (2020)

Numerically, the differences between these three tiers appear small, but they represent qualitative distinctions in EU membership. The core group countries participate in all EU policies at the highest level of integration. They are both in the Eurozone and the Schengen area and adhere fully to the internal and external security acquis. Their differentiations are minor (restrictions to land ownership of foreigners and non-participation in the Prüm Convention). By contrast, Denmark and the UK have optouts from monetary union, justice and home affairs, defence and Schengen (UK). The semi-periphery is less coherent as a circle of integration but entirely outside the Eurozone. The three countries inbetween the core and the semi-periphery are in the Eurozone but have sporadic differentiations in areas of internal (Cyprus and Ireland) and external security domains (Malta). Croatia is likely to join the semiperiphery in the near future.

In contrast to the mode of multi-speed integration, the distribution of member states across the three tiers does not simply reflect the duration of membership. Whereas all founding members and all countries of the Southern enlargement of the 1980s are in the core, Northern, EFTA, and Eastern enlargement countries are located in different tiers. Third-tier UK and Denmark have been EU members since 1973, whereas six core members only joined in 2004. Even though the correlation between a country's total and ongoing differentiations is strong, the core countries show considerable variation. Whereas the integration of the founding members (and some later joiners such as Austria and Finland) has never been strongly differentiated, other core member states have started from levels of differentiation that were as high as those of the more peripheral members. For instance, Latvia and Lithuania have had as many differentiations as Denmark currently has, but they have reduced them to a single differentiation in the course of time. Other successful cases of catching up are Greece, Estonia, and Slovakia. Together with the inverted-pyramid shape of DI, the core countries with a high number 
of initial differentiations testify to significant permeability and upward mobility in the system of differentiation integration and to high inclusiveness of the core.

Figure 5 represents a snapshot of 2019. However, five years earlier (in 2013), the picture looked very similar, except that Latvia and Lithuania had not joined the core yet and Bulgaria was still in the third tier. Just before Eastern enlargement (in 2003), the founding members, Austria, Finland and the Southern member states already constituted the core; the Northern enlargement countries were in the periphery; and Sweden in-between. The same stratification still holds 16 years later. While enlargement and the post-accession period always introduce movement into the system, long-term members occupy remarkably stable positions.

Moreover, we observe a marked difference in the relative contribution member states have made to differentiations based on accession and reform treaties. Figure 6 sums up all the differentiations ever observed in the EU's treaty law and multiplies them by their duration. The result is a stock of the EU's total differentiation time resulting from treaty reforms and enlargements. The figure shows each member state's share in this differentiation stock. By definition, the six founding members of the EU did not contribute to accession-based DI. Yet, they have almost never stayed out of any deepening of European integration either.

\section{Figure 6 Member states' contributions to differentiation in accession and reform treaties}

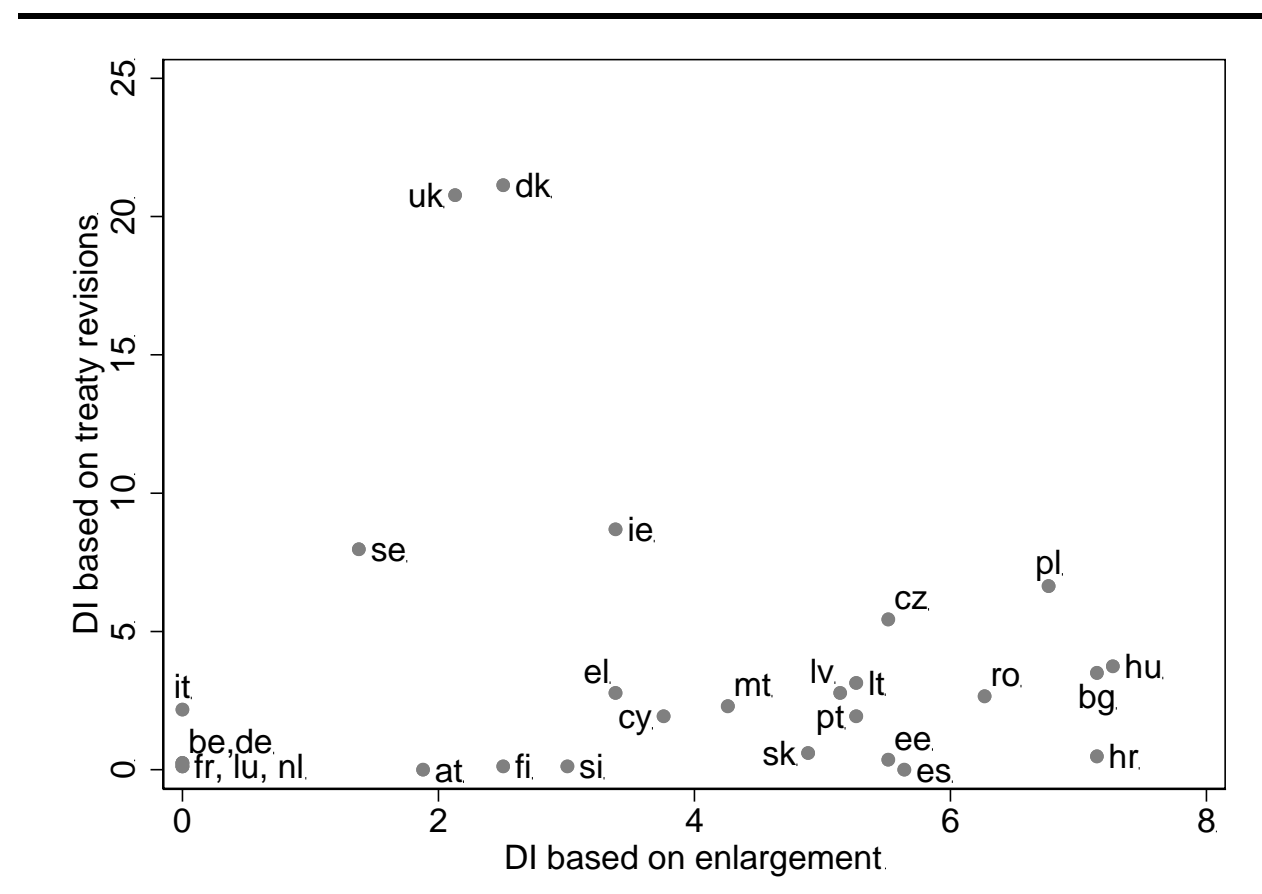

Source: Updated from Schimmelfennig and Winzen $(2014,2020)$. The horizontal axes shows the percentage of enlargement differentiation each EU member state has produced, where 100 percent would be all instances of differentiation in enlargement treaties multiplied by how long they have lasted. The vertical axes shows the same for treaty revisions.

In stark contrast, Britain, Denmark, Ireland and Sweden account for well over 50 percent of all differentiation time in the history of EU treaty reform - Britain and Denmark alone for over 40 percent - whereas their contribution to DI based on enlargement has been weak. With the exception of Ireland, this finding resonates with the common perception of these countries' citizens and parties as relatively Eurosceptic. The Irish case is explicable insofar as maintaining its special relationship with Britain, manifested institutionally in a common travel area, has required it to stay out of the Schengen area.

Most differentiation in enlargement treaties, on the other hand, can be found among the, at the time of their accession, relatively poor and less well-governed countries of the Southern and Eastern 
enlargements. The wealthier accession states in 2004, Cyprus and Malta, produced less differentiation than the rest of their cohort. The EU's Northern and EFTA enlargements comprising wealthy Britain, Denmark, Ireland, Austria, Finland and Sweden also gave rise to comparatively little DI upon accession.

However, it is worth noting that some of the 2004 accession countries might be in the process of transitioning into trajectories similar to Britain and Denmark. The Polish refusal to be bound by the EU's Charter of Fundamental Rights is a sign of such a development. Moreover, countries such as the Czech Republic, Hungary, or Poland were initially excluded from the Eurozone, but now remain outside at least in part because they are sceptical of monetary integration. While the fact that countries join the EU while being poor compared to the then old member states seems to imply that they become subject to temporary DI, it does not rule out that other factors shape their behaviour in subsequent treaty reform negotiations.

The distinct position of the Northern group of countries in the landscape of treaty-based DI mirrors our findings on EU legislation. Not only do Northern countries (Denmark and the UK) populate the outer circle of member states and, together with Sweden and Ireland, share the bulk of opt-outs from EU treaty reforms. They also defied the long-term trend towards uniformity in EU legislation until 2008 and have contributed the most to the subsequent differentiation rally. Indeed, there are many examples suggesting that the Northern differentiations at the treaty and legislative level are institutionally connected. For instance, the Danish decision to opt out of the Union's treaty provisions on internal security policy also implies that it does not participate in legislation adopted on the basis of these treaty provisions. Member states that have not adopted the Euro also do not take part in legislation elaborating the rules of the common currency.

Finally, has the stratification of the EU increased or decreased over time? Based on the annual standard deviation of the number of treaty-based differentiations for each member state, Figure 7 shows that we can actually observe a process of overall divergence. Whereas there have been periods, in which the differentiated integration of the member states has become more alike (e.g. between 1973 and 1980 or 1990 and 1993), the overall trend is one of member states drifting apart. Until the mid-1990s, short periods of divergence were followed by a return to earlier levels of similarity, but divergence has outpaced convergence ever since. This trend suggests that the multi-tier structure of the EU has become more pronounced over time. The figure shows that both the level of DI (measured as the mean number of differentiations across member states) and the variation in DI across member states have increased markedly since the mid-2000s. In recent years, divergence has reached new record highs against a rather stationary development of the level of DI. 
Figure 7 Divergence in multi-tier EU integration

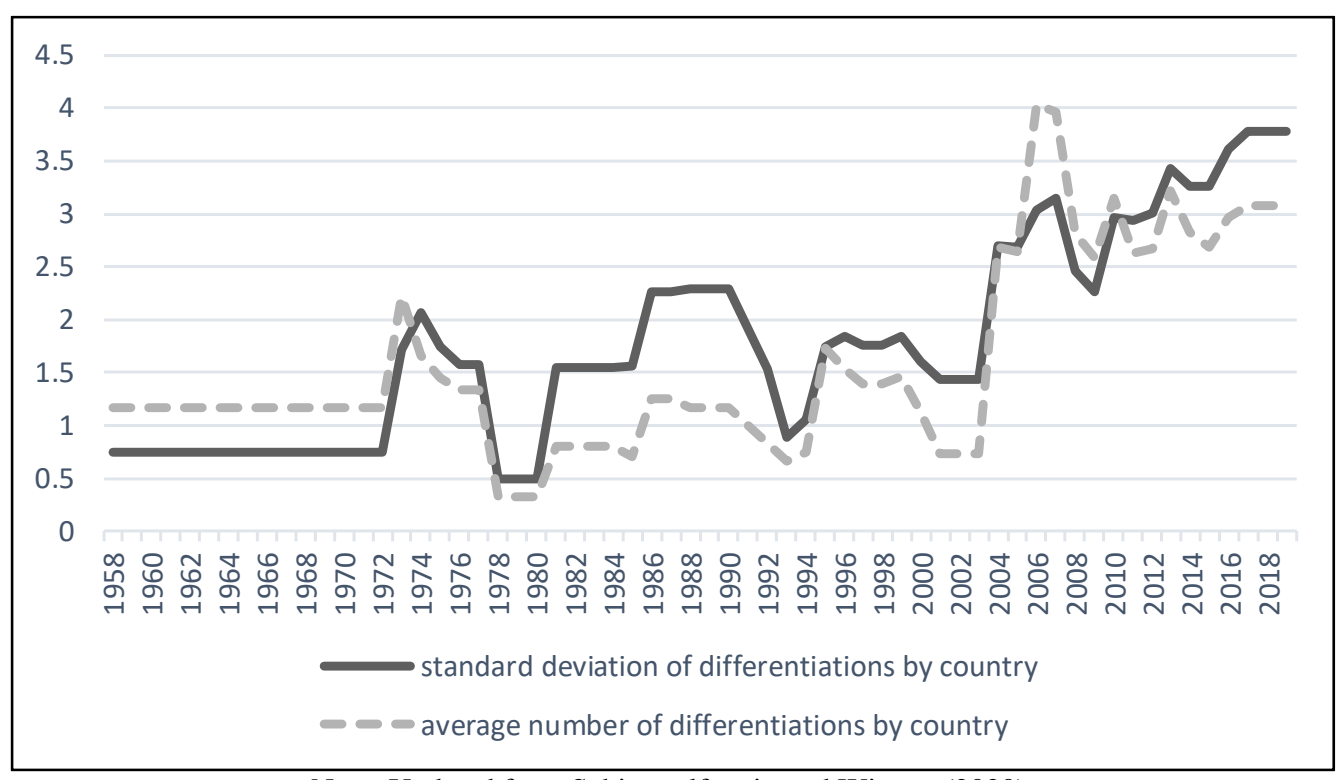

Note: Updated from Schimmelfennig and Winzen (2020).

In sum, the dominant multi-speed mode of EU differentiated integration has been accompanied by the establishment and consolidation of a multi-tier structure since the 1990s. Multi-tier integration features a large and open core of (almost) uniformly integrated member states, which started with the founding members. Yet its ranks are continuously expanded by the multi-speed integration of new member states when the exemptions and exclusions of their accession period expire. While legislative differentiation has also increased in the core since 2008, it has done so equally across countries. By contrast, the periphery is a small group of integration-sceptic member states with opt-outs from the reform treaties and the accompanying secondary legislation - it has also contributed the most to growing legislative differentiation since 2008. The semi-periphery, finally, consists of aspiring core member states, which have not been capable of overcoming their accession-based differentiations yet (such as Bulgaria, Croatia and Romania), or member states that are unwilling to commit to the deepening of integration required for joining the core (such as the Czech Republic, Hungary, Poland and Sweden). The coreperiphery structure of European integration has become more pronounced in the past decade.

\section{Multi-menu integration: uniform market, differentiated core state policies}

Multi-tier and multi-menu integration both assume durable differentiation, but multi-menu integration draws the boundaries along policies rather than groups of states. This is not what we see in the durable component of DI in the EU. Groups do not organize around distinct policies. Rather, the core member states participate in all EU policies, whereas the peripheries participate in subsets of EU policies. That does not exclude a policy dimension of DI, however. In keeping with the menu metaphor, core and periphery share the two main courses (institutional and market policies), but the core indulges in an extra course of core state powers. Moreover, the policies affected by differentiation vary considerably between enlargement and treaty reform.

For our analysis of the policy dimension of DI, we aggregate 42 individual policy issues reflecting the structure of European treaties and headings of treaty sections into policy areas and further into policy domains (see Table A1 in the Appendix). Table 2 lists these policy areas and domains and shows how primary-law differentiations and their durability are distributed across them.

In the domain of 'institutions', we find no DI at all. All member states share the EU's principles, organizational bodies and the EU budget. This would not be the case had the majority of British voters 
backed Remain and the 'New Settlement' negotiated between the Cameron government and the European Council, which conceded that 'the references to ever closer union do not apply to the United Kingdom' (European Council 2016). A Eurozone Parliament or a Eurozone budget, as proposed by Eurozone reformers, would also introduce DI in the domain of institutions (unless it was codified only in the policy-specific sections of the treaties (as is the ECB and the Eurogroup of finance ministers).

Table 2 Differentiations across policies

\begin{tabular}{lllll}
\hline Domain & Policy & Differentiations & Avg. duration & \% ongoing \\
\hline Institutions & & 0 & 0 & 0 \\
Regulation & Social policy & 1 & 6 & 0 \\
Expenditure & Agriculture & 7 & 10.7 & 0 \\
Market & Free movement & 72 & 8.4 & 14 \\
& Flanking policies & 16 & 4.7 & 0 \\
& Market total & 88 & 7.7 & 11 \\
\hline Core state powers & Foreign policy & 4 & 10.8 & 100 \\
& Interior policies & 72 & 7.3 & 39 \\
& Monetary policy & 58 & 7.9 & 72 \\
& Core state total & 134 & 7.7 & 55 \\
\hline
\end{tabular}

Note: Updated from Schimmelfennig and Winzen (2020).

In expenditure and regulation, more precisely agriculture and social policy, we find few differentiations, all of which have expired. The market and core state policies thus remain as the two relevant policy domains for DI. Almost 40 percent of all differentiations belong to the domain of the market, whereas nearly 60 percent refer to core state powers: foreign and defence, interior and justice, and monetary policies. Typical market examples include limits to the free movement of workers or the freedom to provide services for the eastern European countries that have joined the EU since 2004. Schengen and Eurozone differentiation are widely known and visible as is the fact that, for instance, Britain and Denmark do not participate fully in the Union's internal security policies. Less well-known examples of DI include restrictions on the cross-border acquisition of agricultural land (limiting the freedom of movement of capital). Overall, there is no difference in how long market and core state power differentiations last. Yet whereas only 11 percent of market differentiations are ongoing, more than half of the differentiations in the domain of core state powers (55 percent) were still in effect in 2019. Put differently, 74 of the 84 differentiations ongoing in 2019 (or 88 percent) belong to core state policies. Whereas the market is the typical domain of multi-speed integration, core state powers are the typical domain of durable multi-tier integration. 


\section{Figure 8 Differentiations originating in accession and reform treaties, by policy area}

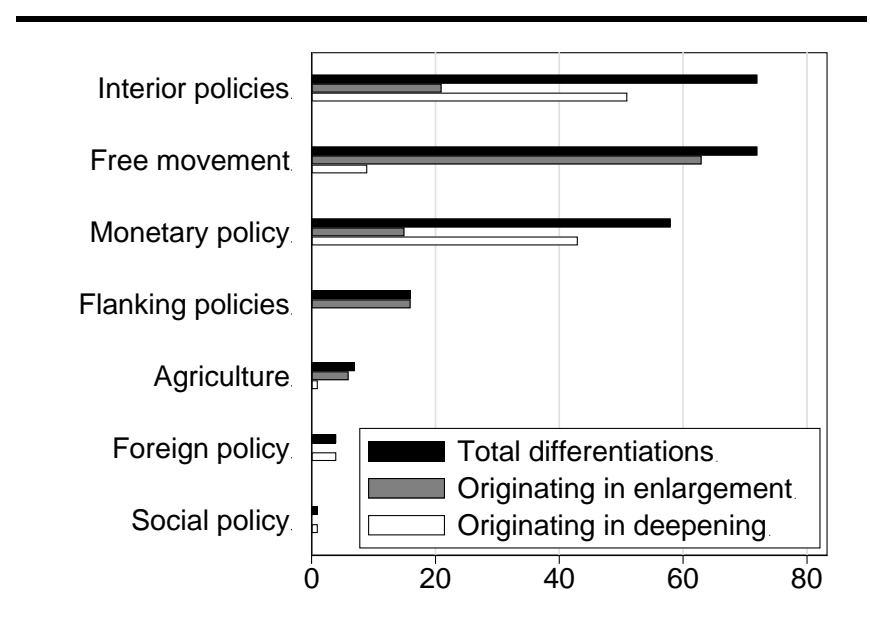

Source: Updated from Schimmelfennig and Winzen $(2014,2020)$.

Moreover, certain differentiated policy areas are also more relevant in enlargement than in treaty reform and vice versa (Figure 8). Market policy differentiations (free movement and flanking policies) arise nearly exclusively in the context of enlargements. These differentiations, as we saw earlier, govern the gradual inclusion of relatively poor newcomers into the EU market. In contrast, treaty reforms produce almost no market differentiation but many opt-outs in core state powers, notably in interior and monetary policy. As the previous sections have shown, these cases of differentiation are generated predominantly by the Union's comparatively sovereignty-sensitive Northern member states. It is nevertheless important that core state powers also give rise to concerns over adequate border protection and currency management by relatively poor member states. Indeed, we also observe noteworthy numbers of differentiation cases in core state powers in the context of accession treaties.

Figure 9 examines policy variation in the differentiation of EU legislation. It offers a nuanced perspective on the initial, long-term trend towards uniformity and the post-2008 rise in legislative differentiation. The long-term trend towards uniformity is visible in most of the EU's market and regulatory policies. In these areas, the overall amount of DI as well as the differences between countries had shrunk to near irrelevance by 2008. Environment and energy policies and (albeit at a low level) consumer protection policies have been more long-standing exceptions from this trend with stable or slightly increasing differentiation. The impact of German unification has been especially pronounced in policies that impose regulatory burdens on the economy. Moreover, these exceptions notwithstanding, the strong rise of differentiation after the 2008 that we saw earlier is hardly visible in the EU's market, spending and regulatory policies - rather we see the consolidation of differentiation at a very low level and at most mild increases. The strongest increase - in the free movement of goods, services, workers, and capital - is predominantly a spill-over from the Eurozone crisis and EU efforts to regulate financial markets, banking, and budgets. Legislation on the Single Supervisory Mechanism, capital requirements, or monitoring of draft budgets and excessive deficits relied on legal bases in the single market sections of the treaties, for example. 
Figure 9 Legislative differentiation by policy areas

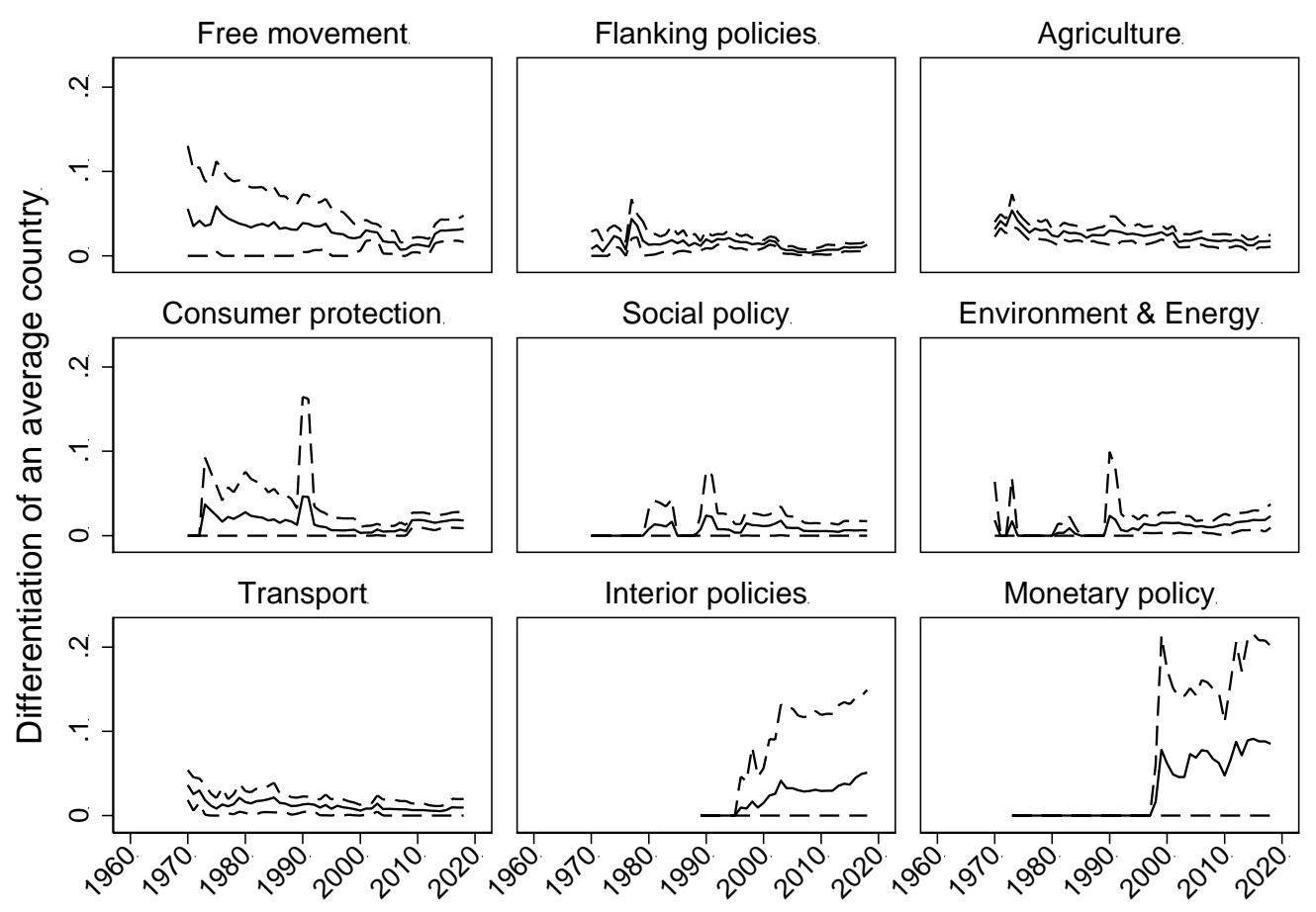

Note: Adapted from Duttle et al. (2017) and updated from Schimmelfennig and Winzen (2020). The figure shows the differentiation opportunities used by an average country plus/minus one standard deviation (dashed lines). It omits legislation in cohesion and foreign policies and institutional matters since there is little legislation in these areas.

Core state powers are the main exception from the growth and consolidation of uniform integration in EU legislation - and the dominant driver of the differentiation rally since 2008. In interior and monetary policies, legislative differentiation grew quickly in the 1990s and early-2000s alongside developments at the treaty level such as the entry into force of the Schengen Area, the third stage of monetary union, and enlargements. After a consolidation period as new member states joined Schengen and the Eurozone, differentiation has been on the rise again. The main differentiation phases encompass 20112014 (monetary policy) and 2013-2017 (interior policies). In monetary policy, legislation on budgetary surveillance and macroeconomic imbalances. Moreover, with banking union, the differentiation between Eurozone and non-Eurozone member states has spilled over into the internal market (free movement in Figure 9). In interior policies, legislation related to migration and refugee flows has been one key driver - the Dublin III regulation, rules on border surveillance and the European Border and Coast Guard, the registration of entry and exit data for third-country nationals, and travel documents for the return of illegally staying third-country nationals fall into this category. Burgeoning, post-Lisbon legislative activity in justice policies has also contributed to differentiation. Examples include legislation related to the Roadmap for strengthening procedural rights in criminal proceedings, the European Public Prosecutor's Office, fraught against the Union's financial interests, or attacks against information systems.

Northern European member states have driven core state power differentiation not only at the level of treaties but also in the Union's legislation. Figure 10, which aggregates the EU's competences into four broad domains, shows that Britain, Denmark and Ireland have on average used over 25 percent of their legislative differentiation opportunities in core state powers compared to less than 5 percent in the case of all other groups of member states. Overall, the other cohorts have remained at low levels even in recent years but have all contributed to growing differentiation. The Eastern and EFTA cohorts in 
which several countries retain Eurozone and interior policy opt-outs have been the main sources of differentiation except for the Northern cohort.

In sum, internal differentiation in the EU does not follow the mode of multi-menu DI, in which we would see varying groups of countries organized by different policy areas. Rather, policies are embedded in a hierarchical, multi-tier structure, in which the core is integrated in all policies at the highest level, whereas the lower tiers opt out, or are excluded, from one or more policies.

\section{Figure 10 Legislative differentiation for groups of members in the EU's major policy domains}

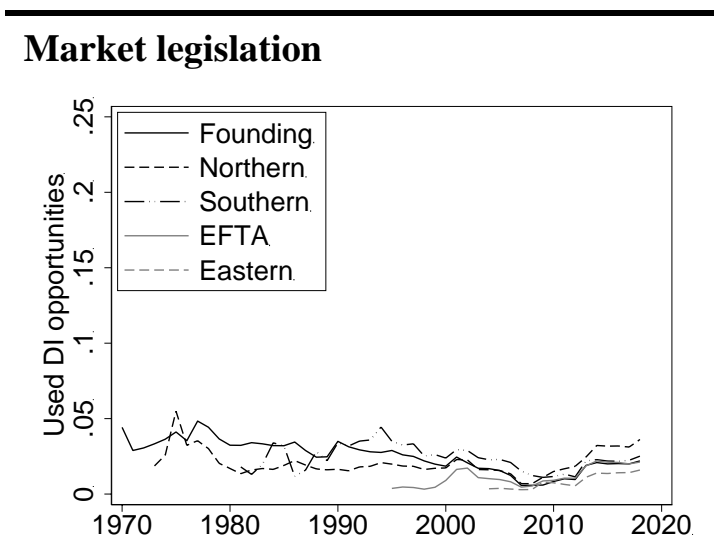

\section{Expenditure legislation}

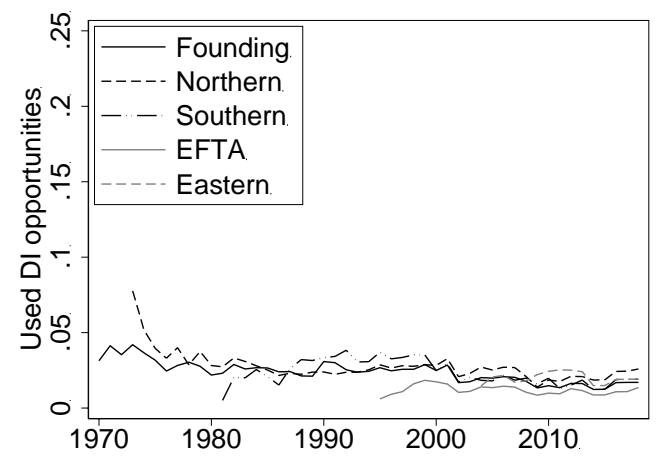

\section{Regulatory legislation}

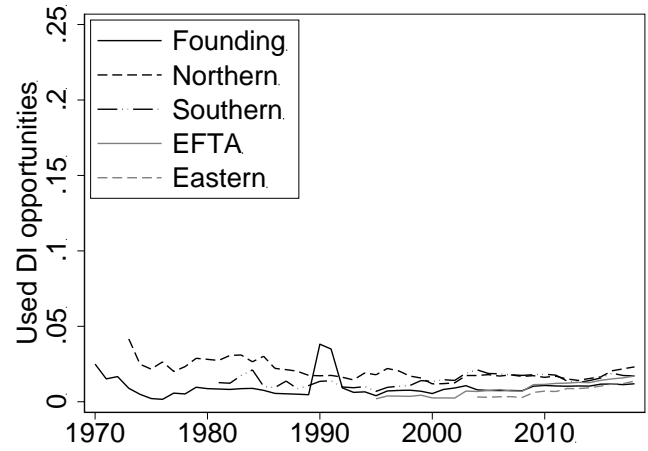

\section{Core state power legislation}

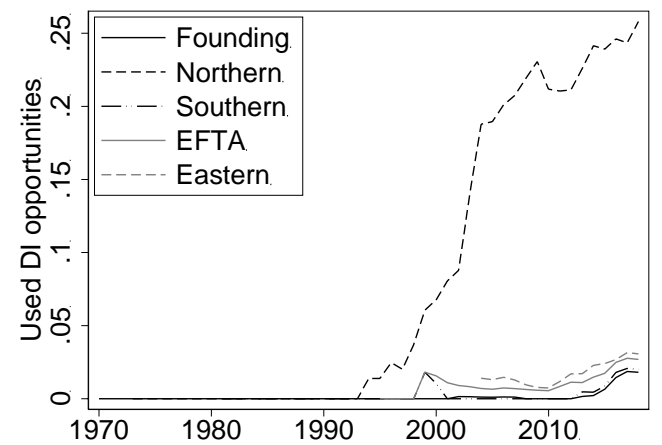

Source: Adapted from Duttle et al. (2017) and updated from Schimmelfennig and Winzen (2020). The figures show the share of differentiation opportunities used by member states. The domain 'Institutions' is omitted since it contains very little EU legislation.

Yet, DI clearly has a policy dimension. First, formal institutions are the domain of (almost) uniform treaty-based integration. New member states enjoy full member status in the EU's institutions from day one of membership, and opt-outs do not pertain to the general institutional principles, bodies and procedures of the EU. Participation in the institutions and procedures defines what it means to be an EU member state beyond varying participation in the EU's policies. Second, the market is the domain of multi-speed Europe. Differentiations in market freedoms and the market-correcting regulatory and redistributive policies are highly likely to end after a reasonable period of time. Member states of all tiers participate (nearly) uniformly in the market and related policies. These areas have contributed little to the recent rise of differentiation and, if so, mainly as a result of spill-overs from the governance and reform of the Eurozone. Finally, core state powers are the domain of multi-tier Europe. Core member states make core state policies, and (the integration of) core state powers makes core member states. 


\section{Outlook: stagnant integration and Brexit}

This report is based on data ending in 2019 for EU treaties and 2018 for EU legislation. Yet differentiated integration is an ongoing process shaped by processes of enlargement, treaty reform and legislation. Moreover, it is by no means clear that the future development of DI will necessarily continue the trends and patterns that we have observed. In the past, the Treaty of Maastricht establishing the European Union and the expansion of European integration from market to core state policies constituted a breaking point in the development of DI. The withdrawal of the UK from EU membership might generate another one. Whether the recent rise of differentiation in the aftermath of the multiple crises that the EU has faced over the past decade will continue, consolidate or decline remains to be seen as well. In this section, we will therefore take a look at recent developments in DI and speculate about its future trajectory.

Enlargement has always been a major source of differentiation in European integration. Future enlargement is therefore likely to increase the number of total and ongoing differentiations in the EU. However, since Croatia's accession in 2013, EU enlargement has been on hold. Whereas Montenegro, Serbia and Turkey have started accession negotiations many years ago - and Albania and North Macedonia are about to be invited - none of these countries will be able to join the EU in the near term, and Turkey's accession prospects are non-existent under the current circumstances. It is therefore unlikely that EU accession treaties will introduce any new differentiations in the foreseeable future.

At the same time, those countries that have joined the EU most recently - Bulgaria, Croatia and Romania - have not only started their membership with a comparatively high level of differentiation, but also remained at this high level for a long time (see Figure 3). This observation lets us expect that future members from the same region (Southeast Europe) are likely to repeat the same pattern. It seems, moreover, that both the recent and any future enlargements may deviate from the past pattern of multispeed differentiation and quick approximation of old member states' levels of differentiation. Rather, enlargement may become an additional source of durable, multi-tier differentiation in the future. The conclusions are contradictory: whereas additional enlargement-based differentiations are unlikely to appear in the near future, they will likely be more numerous and more durable if and when enlargement happens.

Considering future treaty revisions produces similar predictions. The Treaty of Lisbon of 2009 was the most recent major revision of the EU's basic treaty framework. A similar overhaul of the main treaties is not on the cards - both because of disagreement among the member states about the desirability and the direction of such a revision and because of high uncertainty about domestic ratification in a highly politicized EU. Instead member states have concluded several intergovernmental agreements outside the main treaties in order to consolidate the Eurozone and agreed on PESCO in the area of defence policy. All these agreements have been and remained differentiated.

Moreover, existing differentiations from earlier treaty revisions have remained stable in recent years. Since the major expansion of the Schengen area in 2007, no treaty-based differentiation in the areas of internal and external security policies has ended. Whereas Croatia is likely to be first in line to join the Schengen area, eventually to be followed by Bulgaria and Romania, it is not clear yet when this will happen. Yet these are differentiations originating in accession rather than opt-outs from treaty revisions. Likewise, the expansion of the Eurozone has stalled since the last Baltic country, Lithuania, joined in 2015. Whereas Bulgaria, Croatia and Romania are eager to adopt the euro, their accession to the Eurozone is likely to take longer than their accession to the Schengen area. The Czech Republic, Hungary and Poland currently have no Eurozone membership aspirations at all. In both central domains of durable treaty-based differentiation, none of the original opt-out countries (Denmark, Ireland, Sweden and the UK) has modified their stance. In sum, while new treaties producing additional differentiations are not on the horizon (in the absence of new major integration crises), existing differentiations from treaty revisions will most likely remain stable. If treaties are revised, however, these revisions are likely to produce significant additional DI. 
The EU's system of differentiated integration has faced multiple significant shocks in recent years: the Eurozone and refugee crises as well as Brexit. The first two crises produced extensive new legislative differentiation as they affected policies that were not only highly salient but also already differentiated at the treaty level. Whereas core member states faced pressure to respond to the crisis with new legislative measures, countries in the periphery and semi-periphery often refrained from adopting these measures. Yet, will the growth of differentiation continue? In the case of the Eurozone, a stabilization at existing levels is more likely and in fact what we observe in the most recent years. The largest legislative projects related to Banking Union have been adopted. Furthermore, the Eurozone has always been light on legislation, but demanding in monitoring and implementation so that it is unlikely to produce much differentiation in the near future. A quick return to pre-crisis levels of uniformity is unlikely either because legislative differentiation largely follows the treaty-based multi-tier structure and can only change significantly if new countries join the Eurozone.

In the case of internal security and justice policies, some of the new differentiation again maps on existing treaty-based opt-outs and is unlikely to decline. However, unlike in the Eurozone, a significant share of differentiation comes from member states without treaty-based opt-outs and from routine legislative activity since Lisbon. As the EU continues to develop its judicial system, further differentiation might thus arise. While countries can also give up differentiation more easily if they do not have to overcome treaty-level differentiation, this has not been the norm in core state powers so far except for new member states. In internal policies, differentiation is thus likely to remain stable at least or grow further, albeit gradually due to routine legislation rather than suddenly due to crises.

Finally, as crisis-related differentiation pressures cease, and the EU returns to the production of market-related legislation, overall legislative uniformity in the EU is likely to increase again. Legislative activity in the market and associated policies has always dwarfed core state power legislation and has contributed only little and indirectly to the recent increase in differentiation. It is likely to reduce overall differentiation over time and potentially return the EU to the long-term consolidation trend that it had followed at the level of legislation until 2008.

Brexit is the most important current shock to the EU's system of differentiated integration. The direct consequences of the UK's withdrawal for DI are easy to quantify. Brexit reduces the number of ongoing treaty-based differentiations from 84 to 73 (by 13\%). Together with the expiring free-movement restrictions for Croatia, Brexit will thus bring down treaty-based differentiation to a level not seen after 2005 in absolute terms (except for a brief interlude in 2011). Weighted by the number of member states and policies, it will be lower than at any time since 2003, i.e. before the big-bang 2004 enlargement. Whereas DI will not return to pre-Eastern enlargement levels, it will reach a post-Eastern enlargement low. Moreover, Brexit will reverse the recent trend towards divergent differentiation among the member states and bring it down to a level last seen before the euro crisis reforms.

Because the British opt-outs belong almost exclusively to the domain of core state policies, Brexit will reduce differentiation in the areas of monetary policy, internal and external security policies and fundamental rights. By contrast, Brexit will not have a major effect on DI in the EU's internal market policies (which are not strongly affected by differentiation anyhow).

Finally, Brexit will have a visible effect on the multi-tier structure of DI. Without the UK, Denmark will remain the only country in the peripheral tier of DI. Without the UK, and given that Croatia will move closer to the current semi-periphery, it will probably be more appropriate to speak of Denmark as an outlier in a two-tier system of DI (see Figures 5 and 6). In addition, the Irish opt-out from Schengen and the EU's justice and home affairs policies - and the Polish opt-out from the Charter of Fundamental Rights - will look more awkward after the UK leaves.

More than the quantitative changes, these structural changes in the EU's system of differentiated integration raise the issue of indirect and qualitative effects of Brexit. As a large member state with a high number of opt-outs from integration in core state policies, the UK has served as an anchor country of differentiated integration in the EU. It has stood for and propagated DI as an alternative to 'ever closer 
union' and put critical mass behind this alternative. It has thereby lent DI both viability and legitimacy. While Denmark and other countries with a comparatively high level of differentiation are unlikely to follow the UK out of the EU, they will not be able to follow in the UK's footsteps as an anchor of multitier integration either. Nor will any of the other larger member states. Brexit may thus not only reduce the probability of further differentiation in future treaty negotiations and legislation. It may also create pressures on peripheral countries to reconsider and reduce their opt-outs from monetary union, interior policies and defence.

To summarize, current conditions of European integration point to consolidation and more uniformity in the EU system of differentiated integration. The stagnation of the EU's widening and deepening, the end (for now) of two major crises, and the exit of the 'champion' of DI, suggest that the dynamics of differentiation will pause as well. If the EU has used DI to facilitate the deepening and widening of integration to more contested policy areas and diverse member states, it is only consequential that differentiation declines if integration slows down and the most Eurosceptic member states leaves. Perhaps counterintuitively, the consolidation and decline of differentiation is a symptom of stagnation and exit, not progress and dynamism, in European integration.

\section{Conclusion}

This report set out to map patterns and trajectories of DI throughout EU history, across all member states, policy areas, in treaty law and legislation. Several of this chapter's findings conform to the conventional wisdom that DI has been on the rise. In treaty law and legislation, this clearly is the case in core state powers such as monetary policy and for member states such as Britain and Denmark. Moreover, the almost continuous process of enlarging the EU-since 1970, 19 countries have joined the founding six in seven enlargements - has meant that exceptions and discriminatory provisions of the accession treaties have added to the stock of DI at any given point in time. Some new member states such as the Czech Republic and Poland have even started to pursue policies similar to those of the more nationalist old member states and have increased the Union's legal differentiation. Finally, the EU's most severe crisis so far - the Eurozone crisis - has added more differentiated intergovernmental agreements and contributed significantly to the recent upshot in legislative differentiation.

This report also shows a less noticed story of consolidation. First, the EU's institutional core has remained largely undifferentiated. The basic principles, rules of decision-making, and policy-making institutions are used by all countries. Ideas such as the creation of a separate Eurozone parliament have not been realized. Whereas an increasing number of intergovernmental treaties outside of the EU's legal framework (e.g. the ESM Treaty) challenge the institutional core, so far, all these treaties contain firm commitments for future incorporation into the EU treaties - a practice already known from the Schengen and Prüm treaties in the area of interior policy.

Second, almost all differentiation resulting from the accession of new member states to the EU proves to be temporary. New member states are almost uniformly integrated after 5-10 years of membership. Whereas the most recent members of the EU are taking longer to overcome their accession-based differentiations, this is a function of their high initial level of differentiation and their comparatively weak quality and capacity of governance. Finally, in the shadow of the much-debated differentiation of core state powers, the EU's market, regulatory and agricultural rules have experienced a long-term trend towards nearly comprehensive uniformity in secondary legislation. Most differentiation in these areas happens at the treaty level, in the enlargement context, and is temporary. The recent uptick in differentiation in the market domain is, to a large extent, a spillover from the differentiated reform of the Eurozone, extending to the financial market of the EU (banking union).

The analytical distinction of modes of differentiation is not only of conceptual use but also helps us to better appreciate the nature of DI in the EU. Differentiated integration in the EU is predominantly multi-speed integration. The large majority of differentiations in EU rules are temporary, and they expire 
after a limited period of time. Most of them are designed to facilitate the entry of new member states, and they disappear as membership endures and new member states adapt to EU policies and increase their state capacity. In addition, however, the EU has accumulated an increasing stock of durable differentiations since the 1990s. The unequal distribution of these durable differentiations across the member states reveals a multi-tier structure, in which a large majority of member states has formed the stable core of (almost) uniformly integrated member states and a minority of Northern (and, increasingly, Eastern) Eurosceptic member states has opted out of the integration of core state powers. By contrast, we discard the multi-menu mode as an adequate description of the patterns and trajectories of DI, while noting that both multi-speed and multi-tier DI show clear policy variation. Rather than fragmenting the EU into separate 'clubs' or 'many Europes', differentiated European integration has preserved common institutions, in which all members partake, and a core group of member states that participate in all policies. 


\section{References}

Duttle, Thomas, Katharina Holzinger, Thomas Malang, Thomas Schäubli, Frank Schimmelfennig, and Thomas Winzen. 2017. 'Opting out from European Union Legislation: The Differentiation of Secondary Law'. Journal of European Public Policy 24 (3): 406-28.

Schimmelfennig, Frank, and Thomas Winzen. 2014. 'Instrumental and Constitutional Differentiation in the European Union'. Journal of Common Market Studies 52 (2): 354-70.

Schimmelfennig, Frank, and Thomas Winzen. 2020. Ever Looser Union? Differentiated European Integration. Oxford: Oxford University Press.

Stubb, Alexander. 1996. 'A Categorization of Differentiated Integration'. Journal of Common Market Studies 34 (2): 283-95.

\section{Appendix}

Table A1 Policy areas in European integration

\begin{tabular}{|c|c|c|}
\hline Policy domain & Policy area & Policy issue (42) \\
\hline \multirow[t]{2}{*}{ Market } & Free movement & $\begin{array}{l}\text { Free movement of goods, services, workers, and capital, } \\
\text { freedom of establishment (5) }\end{array}$ \\
\hline & Flanking policies & $\begin{array}{l}\text { Competition, taxation, economic policy, industry, tourism, } \\
\text { research and technology (6) }\end{array}$ \\
\hline \multirow[t]{2}{*}{ Expenditure } & Agriculture & Agriculture (1) \\
\hline & Cohesion & Economic and social cohesion (1) \\
\hline \multirow[t]{4}{*}{ Regulation } & \multirow{4}{*}{$\begin{array}{l}\text { Consumer protection } \\
\text { Social policy } \\
\text { Environment \& energy } \\
\text { Transport }\end{array}$} & Consumer protection, public health. civil protection (3) \\
\hline & & Social policy, employment policy (2) \\
\hline & & Environment, energy (2) \\
\hline & & Transport, Trans-European Networks (2) \\
\hline \multirow[t]{3}{*}{$\begin{array}{l}\text { Core state } \\
\text { powers }\end{array}$} & Foreign policy & $\begin{array}{l}\text { Common foreign and security policy; development cooperation } \\
\text { (2) }\end{array}$ \\
\hline & Interior policies & $\begin{array}{l}\text { Justice and home affairs; visa, asylum, immigration } \\
\text { Schengen; Prüm; Charter of Fundamental Rights (5) }\end{array}$ \\
\hline & Monetary policy & $\begin{array}{l}\text { Monetary policy; ESM Treaty; Fiscal Compact; Single Resolution } \\
\text { Fund (4) }\end{array}$ \\
\hline Institutions & Institutions & $\begin{array}{l}\text { Principles, institutional provisions, financial provisions, general } \\
\text { provisions, final provisions, approximation of laws, } \\
\text { administrative cooperation, Protocol European Investment Bank, } \\
\text { Protocol privileges and immunities, overseas territories (9) }\end{array}$ \\
\hline
\end{tabular}


Author contacts:

\section{Frank Schimmelfennig}

Center for Comparative and International Studies

ETH Zürich

IFW D45.1

8092 Zürich

Switzerland

Email: franksch@ethz.ch

\section{Thomas Winzen}

Department of Government

University of Essex

Wivenhoe Park

Colchester CO4 3SQ

United Kingdom

Email: thomas.winzen@essex.ac.uk 
With the support of the The European Commission supports the EUI through the European Union budget. This Erasmus+ Programme publication reflects the views only of the author(s), and the Commission cannot be held of the European Union responsible for any use which may be made of the information contained therein. 